\title{
Cross-cultural Adaptation, Reliability and validity of the Turkish Version of the Work Limitations Questionnaire-Short Form
}

\section{İş Limitasyonu Ölçeği Kısa Formu Türkçe Uyarlaması: Geçerlilik ve Güvenilirlik Çalışması}

(1) Ramazan ŞAHIN11, iD Seçil ÖZKAN², id Mustafa Necmi ILHAN²

${ }^{1}$ Gazi University, Department of Occupational Health and Safety, Ankara, Turkey

${ }^{2}$ Gazi University, Department of Public Health, Ankara, Turkey

\begin{abstract}
Objective: The physical or emotional difficulties faced by academicians negatively affect their productivity. The aim of this study is to translate and adapt a Turkish version of the Work Limitations Questionnaire-Short Form (WLQ-SF) and investigate its validity and reliability. The WLQ-SF assesses academicians who have suffered from physical or emotional health limitations in the past 2 weeks while working.
\end{abstract}

Methods: In this study, the mean age of 104 participants who completed the Turkish version of the WLQ-SF was $37.75 \pm 9.43$ years. The test-retest reliability was evaluated using the WLQ-SF with a 7-day interval. The test-retest reliability assessed through intraclass correlation coefficient (ICC) and Cronbach's alpha $(\alpha)$ were used to determine the construct validity and time-invariant reliability of the scale over time.

Results: The WLQ-SF provided construct validity with $68.62 \%$ variance under two factors (Bartlett's test of sphericity value, 407.830; Kaiser-Meyer-Olkin (KMO) value, 0.746; $\mathrm{p}=0.0001$ ) and was found to be valid. It demonstrated a high test-retest reliability (ICC $=0.96$ ) and good internal consistency (Cronbach's alpha $=0.83$ ) for all domains. Therefore, the WLQ-SF in the Turkish language is a valid and reliable test.

Conclusion: The Turkish version of the WLQ-SF was found to be valid and reliable for evaluating the effect of physical and emotional health among academicians. It is an important scale to measure the impact of both physical and emotional health at work.

Keywords: Academicians, work limitation, reliability, validity, Turkish

\section{ÖZ}

Amaç: Akademisyenlerin karşılaştıkları fiziksel ve duygusal zorluklar onların üretkenliklerini olumsuz olarak etkilemektedir. Çalışmanın amacı İş Limitasyonu Ölçeği-Kısa Formu'nun (İLÖ-KF) Türkçe uyarlaması, geçerlilik ve güvenilirlik çalışmasının yapılmasıdır. İLÖ$\mathrm{KF}$ akademisyenlerin son iki hafta içerisinde yaşadıkları fiziksel veya duygusal sağlık durumlarının, çalışma hayatları üzerine etkisini inceleyen bir ölçektir.

Yöntemler: İLÖ-KF'nin Türkçe versiyonuna katılan katılımcıların yaş ortalaması $37,75 \pm 9,43$ yıl olarak hesaplanmıştır. İLÖKF'nin test-tekrar test güvenilirliği yedi gün arayla tekrarlanarak değerlendirildi. Ölçeğin yapısal geçerlilik ve zamana göre değişmezlik güvenilirliği için test-tekrar test intraklass korelasyon (ICC) yöntemi ile Cronbach alfa testi kullanıldı.

Bulgular: İLÖ-KF iki faktör altında \%68,62 varyans ile yapısal geçerliliği sağlamaktadır (Barlett: 407,830; Kaiser-Meyer-Olkin: $0,746, p=0,0001)$. İLÖ-KF güvenilirliği $(I C C=0,96)$ ve iç tutarlılığı (Cronbach alfa $=0,83$ ) oldukça yüksek olarak bulundu. Bundan dolayı İLÖ-KF Türkçe dilinde geçerli ve güvenilir bir testtir.

Sonuç: İLÖ-KF Türkçe uyarlamasının akademisyenlerin fiziksel ve duygusal sağlık durumları üzerinde geçerli ve güvenilir olduğu bulunmuştur. Bu ölçek işyerinde hem fiziksel hem de duygusal sağlığın etkisini ölçmek için önemli bir ölçektir.

Anahtar Sözcükler: Akademisyenler, iş limitasyonu, geçerlilik, güvenilirlik, Türkçe

Address for Correspondence: Ramazan ŞAHIN, Gazi University, Department of Occupational Health and

Received: 16.04 .2020

Safety, Ankara, Turkey

E-mail: sahinramazan88@gmail.com ORCID ID: orcid.org/0000-0002-6218-7558

Accepted: 25.06 .2020

Cite this article as: Şahin R, Özkan S, Ilthan MN. Cross-cultural Adaptation, Reliability and validity of the Turkish Version of the Work Limitations Questionnaire-Short Form. Bezmialem Science 2021;9(3):283-9. 


\section{Introduction}

The concept of work has emerged from social relationships that arise due to the desire to meet the needs of other people (1). Creating or uncovering anything is defined as a process consisting of both physical and mental occupations and labour. Work is an indispensable part of human life that provides an individual with status and value and supports him/her as part of society (2).

The occupational health and safety standards address the conditions of people who are risking their lives and future due to various risk factors and hazards caused by industrialisation and technology. These can be defined as a set of systematic and scientific studies aiming to protect both physical and mental health during the execution of work in the workplace and in an environment free from threats to a person's physical and mental health $(3,4)$. Approximately, $4 \%$ of the Turkey's gross national product is spent on occupational accidents and occupational losses of employees (5). Therefore, measures taken to ensure occupational health and safety will eliminate these losses, and the income earned from being able to continue work will be used to develop the country (6). The need to transform the working environment into a safe and healthy place to protect workers from occupational accidents and diseases must be evaluated for every situation. It should be kept in mind that all kinds of expenditures that are made to improve the occupational health and safety may have a share in minimising the possibility of accidents or injuries, decreasing the costs of the products that a business produces and increasing its profit margin (7).

The profession of an academician can be defined as a civil servant working for a fee, a professional employee or a knowledge worker who can develop fiction works to intersect the intellectual paths within the university (8). As academic staff members work within an academic institution, their performance is evaluated in a way that is similar to that of office workers. Although the working environment of academicians appears to be safer when compared with the hazardous workplaces, they may contain many observed and/or unobserved risk factors (9). Academic staff can work in environments that can be affected by many personal and environmental risk factors, including physical, chemical, biological, psychosocial and ergonomic factors, as observed in other professional groups (10). The main problems that may affect the occupational health and safety of academicians are personal factors, such as workload and stress; psychological factors, such as burnout, depression and anxiety; physical factors, such as inappropriate posture, continuous repetitive movements and ergonomic features of the work environment; and environmental factors, such as noise, thermal comfort, lighting and chemicals (11).

The literature has reported that the costs associated with the loss of productivity in a work environment have a significant economic impact, and additional costs due to paying employees for sick leave and time away from work (e.g. vacations) increase this impact $(12,13)$. When these financial factors are considered, various scales are needed to measure the impact of this health loss of employees on the workplace $(14,15)$. Researchers have adapted some of these scales to different languages. The most frequently used scales are the Job Satisfaction Scale, which is used to evaluate employee satisfaction and personal satisfaction problems, and the Minnesota Satisfaction Questionnaire, which is used to examine the effect of internal and external factors on employee job satisfaction (16-18). The Work Limitations Questionnaire (WLQ) is a scale that is frequently preferred because it evaluates the relationship between the physical health and emotional problems of the employees and their lives. This scale is often used to determine employee-related influences (14).

Considering that employees' physical or emotional difficulties negatively affect the productivity of the business, the present study aimed to ensure the validity and reliability of the Dr Debra Learner's WLQ-Short Form (WLQ-SF), when adapted into Turkish, to examine the effect of physical and emotional situations on employees in the past 2 weeks.

\section{Methods}

Before beginning the study, permission was obtained from the authors of the original version of the WLQ-SF for its translation and validation in the Turkish language. The study was designed according to the Helsinki Declaration, and all the participants signed the consent form. The study was approved by the Ethics Committee of University.

\section{Study Population}

The study was conducted on the academicians working at the Faculty of Health Sciences from March 2019 to June 2019. These academicians were eligible to be part of the study if they met the following participation criteria: 1) Aged between 25 and 65 years; 2) working as a faculty member at a state university; 3 ) having at least 3 years of academic experience and 4) are literate and willing to join the study. Participants were ineligible if they had any chronic, physical, mental and/or cognitive disease as diagnosed by a medical doctor.

In the calculation of the sample size required for performing the adaptation, reliability and validity analyses, it was envisaged that the number of items in the model should be evaluated 10 times as suggested in the study by Tabachnik et al. (19) to make reliable inferences in multivariate analyses. Therefore, the number of individuals to be included for assessing the 8-item scale was calculated to be 80 . It was found that the inclusion of 100 participants with a considered non-response rate of 25 would be sufficient to obtain the necessary working power.

During the study process, 110 participants, who were working as faculty members at various state universities, were included. Of these, six participants were subsequently excluded (four did not come for the test-etest and two requested to be removed from the study). As a result, our final study population consisted of 104 academicians.

\section{Instruments}

A socio-demographic form, comprising questions about age, sex, academic experience and title, were filled out by all the participants. 
The Work Limitations Questionnaire Short Form (Dr. Debra Learner's WLQ-SF) consisted of five sub-parameters and eight questions, which were selected from the WLQ, developed in 2001. The WLQ consists of 25 items that are used to evaluate the physical and emotional limitations of employees and how these affect their ability to perform the job (14). The WLQ-SF takes 10-15 minutes to complete, and it uses two questions from four dimensions related to the on-the-job work demands: time management, physical demands, mental-interpersonal demands and output demands. The recall period is 2 weeks with response categories capturing the percentage of time an employee has for meeting the respective work demand. Response options include "all of the time (100\%)", "most of the time", "some of the time (about 50\%)", "a slight bit of the time," "none of the time (0\%)" and "does not apply to my job". A six-point Likert scale (1-6) is used for each question, allowing workers to answer items. The two physical demand questions used a reversed scale; therefore, they were reversed scored. To calculate the percentage of time an employee was unable to meet his/her job demands, the responses were converted to percentages and the average was measured to obtain a score in the range of $0-100$. Therefore, an index score of 0 represents an employee who is never unable to meet his/her job demands; whereas, a score of 100 represents an employee who is always unable to meet his/her job demands.

\section{Translation and Coss-cultural Adaptation}

The WLQ-SF was translated from English to Turkish according to the standard methodology recommended by Beaton et al. (20). In Stage 1 , two independent translators whose native language was Turkish did the translation of the WLQ-SF. After the synthesis of the translated versions by two native speakers, the final version of the translation was developed in Stage 2. The final Turkish version of the questionnaire was translated back from Turkish into English again by two native English speakers who could speak Turkish fluently (Stage 3). In Stage 4, this version was compared with the original version to identify any inconsistencies. No inconsistencies were found between the Turkish and the original version. Lastly, the pre-final version of the assessment was piloted in academicians $(n=20)$ to determine the clarity of all of the items and their compatibility for Turkish participants (Stage 5). The aim of cross-cultural adaptation was to make consistency in the construct validity between the original and translated versions of the assessment scale. The WLQ-SF was evaluated twice in 104 participants with a 7-day interval to assess the test-retest reliability.

\section{Statistical Analysis}

The Statistical Package for Social Sciences version 23.0 for Windows was used in the analysis of the data collected within the scope of the study. Statistical data were expressed as mean \pm standard deviation $(\mathrm{X} \pm \mathrm{SD})$, median or percentage (\%). The one-sample Kolmogorov-Smirnov test was used to determine the suitability of the data for normal distribution.

\section{Construct Validity}

The validity of the WLQ-SF scale was analysed by descriptive factor analysis. To evaluate the suitability of the factor analysis model, the following properties were searched: chi-square score greater than 0.05 , CMIN/DF value between 3 and 5, cognitive flexibility inventory (CFI) value greater than 0.9 , Tucker-Lewis index (TLI) value greater than 0.9, and RMSEA value less than 0.08 . In the absence of a model fit, construct validity was evaluated by explanatory factor analysis. The Kaiser-Meye-Olkin $(\mathrm{KMO})$, Bartlett's sphericity $(\mathrm{p}<0.05)$ and Bartlett's chi-square values were analysed to assess the model fit through explanatory factor analysis.

\section{Reliability}

In our study, the test-retest reliability measured through Cronbach's alpha $(\alpha)$ and intraclass correlation coefficient (ICC) were used to assess the reliability of the scale over time. The acceptable value for the calculated coefficient with a Cronbach's alpha ranging from 0 to 1 is considered to be 0.80 and above for a previously developed scale, and 0.70 and above for a newly developed scale is interpreted as acceptable (21-23).

\section{Results}

\section{Descriptive Statistics}

In this study, 104 academicians completed the test and retest assessments. The mean age of the participants was $37.75 \pm 9.43$ years $($ minimum $=27$ and maximum $=64)$. Table 1 shows the demographic characteristics of participants.

\section{Construct Validity}

The descriptive factor analysis model used to evaluate the construct validity of the WLQ-SF was not found to be suitable (CFI $=0.62$, chi-square: 151.796 and $\mathrm{p}<0.05$; CMIN/DF: 7.5; TLI: 0.5; RMSEA: 0.25). In light of these data, explanatory factor analysis was used to assess validity. The WLQ-SF provides construct validity with a variance of $68.62 \%$ under two factors (Bartlett's test of sphericity value, 407.830; KMO value, 0.746; $\mathrm{p}=0.0001)$. Questions 1, 2 and 5-8 were distributed as factor 1 (workload and concentration limitation) and questions 3 and 4 were distributed as factor 2 (physical limitations of the working environment) (Table 2). In addition, there are two factors in our study. The factor 1 covers six questions based on the workload and concentration limitation as a single factor. As the questions of the scale used in our study did not distribute too many factors, rotation was not performed.

\section{Reliability}

The Cronbach's alpha was 0.83 for the whole scale, indicating that the scale has high internal consistency. When questions were excluded, the Cronbach's alpha of the scale ranged from 0.70 to 0.83 (Table 3).

Repetition of the form is a reliability analysis that is used in cases where it is possible to reach the same sample again. In this study, the reliability of the WLQ-SF was evaluated using this method. The scale was directed to 104 participants in the first application and re-commissioned to 104 people in the second application. The data obtained from the two applications were tested using the Pearson correlation coefficient. The obtained data were found to be statistically significant (Table 3). 
Table 1. Some of the descriptive characteristics and distribution of participants

\begin{tabular}{l|l|l|}
\hline Characteristics & & $N(\%)$ \\
\hline Sex & Female & $76(73.1)$ \\
\hline & Male & $28(26.9)$ \\
\hline Marital status & Married & $82(78.8)$ \\
\hline & Single & $15(14.4)$ \\
\hline Title & Divorced & $7(6.8)$ \\
\hline & Research assistant (MSc) & $25(24)$ \\
\hline & Research assistant (PhD) & $18(17.3)$ \\
\hline & Assistant professor & $20(19.2)$ \\
\hline & Associate professor & $21(20.3)$ \\
\hline
\end{tabular}

Table 2. Factor analysis of the WLQ-SF

Factor components

Workload and concentration limitation

0.797

Question 1

Question 2

0.747

Question 3

Question 4

Question 5

Question 6

Question 7

Question 8

Eigenvalue

Variance (\%)

\section{Discussion}

The Turkish adaptation of the WLQ-SF, which examines the effects of physical and emotional health conditions on working lives, has been found valid and reliable. Many studies have shown that individuals working as academicians have high psychological and emotional fatigue. Therefore, burnout levels are higher than that among other occupational groups $(10,24,25)$. To evaluate these emotional conditions, we used the WLQ-SF with academicians.

The WLQ-SF uses eight questions to examine four main areas: time management, physical demands, mental-interpersonal demands and output demands. The questions are based on two factors: workload and concentration limitation, and physical limitations of the working environment. Questions about workload and concentration limitation are mostly used to evaluate emotional and psychological effects on participants' workloads. Questions about physical limitations of the working environment assess the physical influences on participants. In our study, we examined the emotional and physical job limitations in our participants. The answers suggested that the emotional and physical limitations made it difficult for all of the participants to perform their job duties well. In other words, it was found that the emotional and physical difficulties that might affect the academicians' work were not very high and their average score in all fields was below $40 \%$. The results of the studies performed in some occupational groups with chronic diseases using this test are similar to the results of our study, given the four main areas mentioned in the test (14,26-31).

To determine the construct validity of the WLQ-SF scale, firstly, we evaluated whether the data collected for the study were suitable for factor analysis and whether the sample size was sufficient. The value of KMO test was 0.746 and the result of Bartlett's test of sphericity was found to be statistically significant $(<0.001)$. These results show that the study sample is sufficient for factor analysis (32). In the explanatory factor analysis, the WLQ-SF scale was found to be two-factor in accordance with the literature $(30,31)$. The factor loadings of the scale ranged between 0.669 and 0.854 . In the literature, although validity and reliability studies were conducted for the WLQ-SF scale in 
Table 3. Item, subscale and scale descriptive and reliability measurements $(N=104)$

\begin{tabular}{|c|c|c|c|c|c|}
\hline & Mean \pm SD & a if item deleted & Item/scale correlation & Cronbach's a & Test-retest reliability (ICC) \\
\hline WLQ-SF & & - & - & 0.83 & $0.960^{*}$ \\
\hline Question 1 & & 0.802 & 0.652 & - & \\
\hline Question 2 & & 0.708 & 0.603 & - & \\
\hline Time management & $38.10 \pm 28.85$ & - & - & 0.781 & $0.985^{*}$ \\
\hline Question 3 & & 0.838 & 0.370 & - & \\
\hline Question 4 & & 0.836 & 0.374 & - & \\
\hline Physical demands & $33.78 \pm 15.75$ & - & - & 0.866 & $0.986^{*}$ \\
\hline Question 5 & & 0.808 & 0.615 & - & \\
\hline Question 6 & & 0.816 & 0.543 & - & \\
\hline Mental-interpersonal demands & $33.89 \pm 25.52$ & - & - & 0.763 & $0.970^{*}$ \\
\hline Question 7 & & 0.791 & 0.736 & - & \\
\hline Question 8 & & 0.806 & 0.617 & - & \\
\hline Output demands & $40.86 \pm 28.58$ & - & - & 0.826 & $0.971^{*}$ \\
\hline
\end{tabular}

12 other languages, the factor contents of these studies could not be found (33). While evaluating the study of the original WLQ (25 questions) conducted in 2001, we found that the questions examining the four main areas had two-factor structure similar to our study. According to the results of our study, the WLQ-SF is a valid test for the examination of job limitations in employees as academicians.

Internal consistency of the WLQ-SF scale was evaluated with Cronbach's alpha in our study. Just as in the original English and subsequent translations, the WLQ-SF scale has excellent internal consistency in all areas $(14,30)$. As a result of the statistical analysis, the coefficient was found to be 0.83 in this study. This result shows that the Turkish version of the WLQ-SF scale is highly reliable since the Cronbach's alpha is between 0.80 and 1.00 .

In this study, Cronbach's alpha was 0.78 for time management, 0.86 for physical demands, 0.76 for mental-interpersonal demands and 0.82 for output demands, which are sub-domains of the WLQ-SF. Considering that the WLQ-SF examines work limitations in these four main areas, it is found that the test is quite reliable in all subheadings. In the original version of the test with 25 questions, the Cronbach's alpha of these four main areas was reported to be 0.88 and above (14). Compared to the results of this study, this difference may be due to the difference in the number of questions between the two tests; however, it may be that the sample group consisted of employees with a chronic disease.
In our study, test-retest results were evaluated with both Pearson correlation coefficient and ICC to test the reliability of the scale. The total and four basic test-retest results were assessed according to the ICC. The results of these analyses indicated that the total of test-retest results and the results of the WLQ-SF scale correlated perfectly between 0.960 and 0.986 .

According to the validity and reliability study of the original WLQ (25 question) in its original language by Lerner et al. (34), the ICC was between 0.690 and 0.860 . Tamminga et al. (29) showed that the test-retest results of the total and 4 based scores in the validity and reliability study of the Dutch version of the scale were between 0.65 and 0.74 (28). Verhoef et al. (28), in the Dutch version of the 25 -question scale, found that the test-retest results based on ICC were between 0.83 and 0.93 (29). Walker et al. (30) in their study using the WLQ-SF found the test-retest reliability based on ICC was between 0.62 and 0.87 . When similar studies in the literature using the WLQ were analysed, it was outlined that the results of this study were similar to the results in both the original language and other languages but were statistically more reliable. In this respect, the results of this study might contribute significantly to the literature.

The WLQ-SF is an important scale that may be preferred in studies regarding detection and prevention of job productivity loss, which is one of the important issues of occupational health and safety. The WLQ-SF is a scale that can be used in different occupations. Therefore, we suggest that future studies with the WLQ-SF in individuals with various professions may contribute to the literature. 


\section{Study Limitations}

The study was conducted only on academicians, which is one of the limitations of our study. Another limitation is that most of the academicians included in this study were working in the faculty of health sciences. If academicians from other faculties were also included, the results could have been stronger or more generalisable.

\section{Conclusion}

The Turkish version of the WLQ-SF was found to be a valid and reliable test for evaluating the effect of physical and emotional health in academicians. The WLQ-SF is an important scale to measure the impact of both physical and emotional health on work. It is also more useful than other scales as it is short, understandable and practical. The WLQ-SF has a two-factor structure, which is in accordance with the literature. Since the factor loadings of the WLQ-SF are between 0.669 and 0.854 , the scale was found to be valid. The internal consistency of the WLQ-SF was found to be high. The test-retest analysis indicated that the invariance of the scale over time was also high. This study is an important and major contribution to the literature as it provides evidence of the validity, reliability and cross-cultural adaptation of the Turkish version of the WLQSF in academicians. The WLQ-SF is a shorter and timesaving alternative to the long form version. Our study provides support for using the WLQ-SF when more comprehensive measures, such as the long form version, are not feasible. Further studies are needed to examine the validity and reliability of the WLQ-SF in different employee samples and work environments.

\section{Ethics}

Ethics Committee Approval: The study was approved by the Ethics Committee of University.

Peer-review: Externally peer reviewed.

\section{Authorship Contributions}

Concept: R.Ş., S.Ö., M.N.İ., Design: R.Ş., S.Ö.,M.N.İ., Data Collection or Processing: R.Ş., Analysis or Interpretation: R.Ş., S.Ö.,M.N.İ., Literature Search: R.Ş., Writing: R.Ş

Conflict of Interest: No conflict of interest was declared by the authors.

Financial Disclosure: The authors declared that this study received no financial support.

\section{References}

1. Christiansen C, Townsend EA. Introduction to Occupation: The art of science and living, 2nd ed. California: Prentice Hall; 2009.

2. Püsküllüoğlu A. Türkçe Sözlük. İstanbul: Yapı Kredi Yayınları; 1995.

3. Özdemir NK. 4857 Sayılı İş Yasası İş Sağlığı ve Güvenliği Hükümlerinin Değerlendirilmesi İş Sağlığı ve Güvenliği. İstanbul: İstanbul Barosu Yayınları. 2004;p. 257.

4. Demircioğlu M, Centel T. İş hukuku, İstanbul: Beta Yayınları, 9. Baskı, 2003; p. 143-66.
5. İlhan MN, Kurtcebe ZÖ, Durukan E, Koşar L. Temizlik işçilerinin sosyodemografik özellikleri ve çalışma koşulları ile iş kazası ve meslek hastalığı sıklığı. Fırat üniversitesi sağlık bilimleri dergisi 2006;20:4339.

6. Ercan A. Türkiye'de yapı sektöründe işçi sağlığı ve güvenliğinin değerlendirilmesi.Politeknik Dergisi 2010;13:49-53.

7. Ünsar S. Türkiye'de İşçi Sağlığı ve İş Güvenliği Uygulamalarının Mevcut Durumu ve Konuyla İlgili Yapılan Bir Araştırma. Sosyal Bilimler Enstitüsü. Unpublished Doctorial Thesis İstanbul: 2003.

8. Tural NK. Universities and academic life in Turkey: Changes and challenges. International Journal of Educational Policies 2007;1:6378 .

9. Ülker Tümlü G, Recepoğlu E. Üniversite Akademik Personelinin Psikolojik Dayanıklılık ve Yaşam Doyumu Arasındaki İlişki. Journal of Higher Education Science 2013:3:205-13.

10. Saygun M. Sağlık Çalışanlarında İş Sağlığı ve Güvenliği Sorunları. TAF Preventive Medicine Bulletin 2012;11:337-82.

11. Aravacık ED. Sağlık hizmetleri bakımından iş sağlığı ve güvenliği. Adli Bilimciler Derneği Dergisi 2014;1-4.

12. Goetzel RZ, Long SR, Ozminkowski RJ, Hawkins K, Wang S, Lynch W. Health, absence, disability, and presenteeism cost estimates of certain physical and mental health conditions affecting U.S. employers. J Occup Environ Med 2004;46:398-412.

13. Loeppke R, Taitel M, Haufle V, Parry T, Kessler RC, Jinnett K. Health and productivity as a business strategy: a multiemployer study. J Occup Environ Med 2009;51:411-28.

14. Lerner D, Amick BC 3rd, Rogers WH, Malspeis S, Bungay K, Cynn D. The Work Limitations Questionnaire. Med Care 2001;39:72-85.

15. Lofland JH, Pizzi L, Frick KD. A review of health-related workplace productivity loss instruments. Pharmacoeconomics 2004;22:165-84.

16. Spector PE. Job satisfaction: Application, assessment, causes, and consequences. California: Sage publications; 1997.

17. Şat A, Doğan H, Amil O. Akademisyenlerin psikolojik ihtiyaçları ve iş doyumlarının bazı değişkenler açısından incelenmesi: Kayseri örneği. OPUS Uluslararası Toplum Araştırmaları Dergisi 2015;5:112-32.

18. Türkçapar Ü. Beden eğitimi öğretmenlerinin farklı değişkenler açısından iş doyumu düzeylerinin incelenmesi. Gazi Üniversitesi Gazi Eğitim Fakültesi Dergisi 2012;32:331-46.

19. Tabachnick BG, Fidell LS, Ullman JB. Using multivariate statistics Boston, MA: Pearson; 2007;(5):203-31.

20. Beaton DE, Bombardier C, Guillemin F, Ferraz MB. Guidelines for the process of cross-cultural adaptation of self-report measures. Spine (Phila Pa 1976) 2000;25:3186-91.

21. Şenocak M. Temel kavramlar ve klinik biyoistatistik. Ankara: Nobel Tip Kitabevleri; 2009; p. 55-61.

22. Zinbarg RE., Revelle W, Yovel I, Li, W. Cronbach's $\alpha$, Revelle's $\beta$, and McDonald's H: Their relations with each other and two alternative conceptualizations of reliability. Psychometrika 2005;70:123-33.

23. Zinbarg RE, Yovel I, Revelle W, McDonald RP. Estimating generalizability to a latent variable common to all of a scale's indicators: A comparison of estimators for $\omega$ h. Applied Psychological Measurement 2006;30:121-44. 
24. Budak G, Sürgevil O. Tükenmişlik ve tükenmişliği etkileyen örgütsel faktörlerin analizine ilişkin akademik personel üzerinde bir uygulama. Dokuz Eylül Üniversitesi İktisadi ve İdari Bilimler Fakültesi Dergisi 2005;20:95-108.

25. Afşar ST. Akademisyenlerin Çalışma Yaşam Kalitesini Hacettepe Üniversitesi Üzerinden Okumak. Eğitim Bilim Toplum Dergisi 2015;13:134-73.

26. Lerner D, Amick BC 3rd, Lee JC, Rooney T, Rogers WH, Chang H, et al. Relationship of employee-reported work limitations to work productivity. Med Care 2003;41:649-59.

27. Tang K, Beaton DE, Amick BC 3rd, Hogg-Johnson S, Côté P, Loisel P. Confirmatory factor analysis of the Work Limitations Questionnaire (WLQ-25) in Workers' Compensation Claimants with chronic upper-limb disorders. J Occup Rehabil 2013;23:228-38.

28. Verhoef JA, Miedema HS, Bramsen I, Roebroeck ME. Using the work limitations questionnaire in patients with a chronic condition in the Netherlands. J Occup Environ Med 2012;54:1293-9.

29. Tamminga SJ, Verbeek JH, Frings-Dresen MH, De Boer AG. Measurement properties of the Work Limitations Questionnaire were sufficient among cancer survivors. Qual Life Res 2014;23:515-25.
30. Walker TJ, Tullar JM, Diamond PM, Kohl HW 3rd, Amick BC 3rd. Validity and Reliability of the 8-Item Work Limitations Questionnaire. J Occup Rehabil 2017;27:576-83.

31. Takegami M, Yamazaki S, Greenhill A, Chang H, Fukuhara S. Work performance assessed by a newly developed Japanese version of the Work Limitation Questionnaire in a general Japanese adult population. J Occupational Health 2014;56:124-33.

32. Akgül A, Çevik O. İstatistiksel Analiz Teknikleri "SPSS'te İşletme Yönetimi Uygulamaları. Ankara: Emek Ofset Ltd. 2003.

33. Work Limitations Questionnaire - Short Form (WLQ-SF).Available at: https://eprovide.mapi-trust.org/instruments/work-limitationsquestionnaire-short-form\#languages .Accessed May 24, 2019.

34. Lerner D, Benson C, Chang H, Rogers WH, Adler D, Lyson MC, et al. Measuring the work impact of caregiving for individuals with schizophrenia and/or schizoaffective disorder with the Caregiver Work Limitations Questionnaire (WLQ). Journal of occupational and environmental medicine 2017;59:1007-16. 